\title{
POSITIONING INDONESIAN ISLAMIC HIGHER-EDUCATION VIS-A-VIS GLOBALISATION: ORGANISATIONAL-RESILIENCE DYNAMICS
}

\author{
Erika Setyanti Kusumaputri ${ }^{1 *}$, Hanifah Latif Muslimah ${ }^{1,2}$, Adib Ahmad ${ }^{1,3}$, Mayreyna Nurwardani ${ }^{1}$ \\ ${ }^{1}$ Universitas Islam Negeri Sunan Kalijaga, Indonesia \\ ${ }^{2}$ Gadjah Mada University, Indonesia \\ ${ }^{3}$ Western Sydney University, Australia \\ *e-mail: erika.kusumaputri@uin-suka.ac.id
}

\begin{abstract}
In the present era of globalisation, higher-education institutions are required to focus on innovation to deal with the various challenges. Considering what Islamic higher-education institutions in Indonesia, have achieved in recent times, they face an uphill struggle to compete at the global level. This study aimed at identifying and analysing the dynamics of resilience for globalisation in a state Islamic-University in Indonesia. The results of studies on the management of Islamic tertiary institutions, specifically on organizational resilience, are very difficult to find. This study used the qualitative analysis method of a case-study and comprised in-depth interviews with key people concerned with the management of the university, observation, and secondary data namely academic documents, photos, and information from the university's official website. The findings showed the university's continuous efforts to improve not only the academic community's management skills, knowledge, and expertise but also the implementation of international-curriculum standardization and cooperation with overseas universities. These actions cannot be separated from obstacles faced by university from within and without particularly in terms of funding-related policies. The university's program-based innovations which are yet to be carried out by other Islamic-universities in Indonesia indicate this institution's initiative to break the obstacles.
\end{abstract}

Keywords: higher-education management, Islamic higher-education in Indonesia, organisationalresilience.

\section{POSISI PENDIDIKAN-TINGGI ISLAM INDONESIA DALAM MENGHADAPI GLOBALISASI: DINAMIKA KETAHANAN ORGANISASI}

\begin{abstract}
Abstrak: Pada era globalisasi dewasa ini, institusi perguruan tinggi dituntut untuk fokus pada inovasi dalam menghadapi berbagai tantangan. Melihat apa yang telah dicapai oleh perguruan tinggi Islam di Indonesia belakangan ini, mereka menghadapi hambatan yang berat untuk bersaing di tingkat global. Penelitian tentang manajemen perguruan tinggi Islam sebelumnya, khususnya ketahanan organisasi, sangat sulit ditemukan. Penelitian ini bertujuan untuk mengidentifikasi dan menganalisis dinamika ketahanan terhadap tantangan globalisasi pada sebuah Universitas Islam Negeri di Indonesia. Penelitian ini menggunakan metode analisis kualitatif studi kasus yang terdiri dari; wawancara mendalam dengan orangorang kunci yang berkepentingan dengan pengelolaan universitas; observasi; dan data sekunder berupa dokumen akademik, foto, dan informasi dari situs resmi universitas. Temuan penelitian ini menunjukkan upaya berkelanjutan yang dilakukan oleh universitas untuk meningkatkan tidak hanya keterampilan manajemen, pengetahuan, dan keahlian sivitas akademika, tetapi juga penerapan standardisasi kurikulum internasional dan kerja sama dengan universitas luar negeri. Dalam pelaksanaan tindakan tersebut tidak lepas dari kendala yang dihadapi oleh perguruan tinggi baik dari dalam maupun dari luar khususnya dalam hal kebijakan terkait pendanaan. Inovasi berbasis program perguruan tinggi, yang masih belum bisa dilakukan oleh perguruan tinggi Islam lain di Indonesia, menunjukkan inisiatif lembaga ini untuk mendobrak kendala tersebut.
\end{abstract}

Kata Kunci: manajemen pendidikan tinggi, pendidikan tinggi Islam di Indonesia, ketahanan-organisasi. 


\section{INTRODUCTION}

The world is experiencing globalisation at present. By the same token, higher-education has to adapt to this global condition. Highereducation must be dynamic enough and ready to face challenges including those pertaining to interactions among countries on many aspects. Higher-education also affected by globalisation (Knight, 2006). International character in modern education in universities is shown in the implementation of professional education, increased academic mobility of students and an increase in the number of foreign students (Kashkan \& Egorova, 2015). The number of student mobility has continued to grow for over 10 years (Kashkan \& Egorova, 2015). Organisation-for-Economic-Cooperation-andDevelopment predicts that by 2020 it will reach 5.5 million and by 2025 as many as 8 million people (OECD, 2008).

Internationalization in universities is one of the goals of education globalization, shaping changes in institutional transformation, in macro policy, namely policy design and decision making, at the middle management level is the structure of the curriculum, and at the level of the study program is the process of teaching and learning (Byram, 2018; de Wit, 2020; Kashkan \& Egorova, 2015; Sá \& Serpa, 2020).

Globalising higher-education has become an equally urgent consideration in Asian countries. It has been an integral part of the national development project to build China's national strength through science and education, called Project-211 and Project-985 (Choi, 2010; Zhou, 2017). The-Brain-Korea-21 (BK21) program launched particularly to nurture globally competitive research-universities (Seong, Popper, Goldman, Evans, \& Grammich, 2008). Similarly, the Japanese government prioritized the internationalisation by targeting 30 public and private universities at both national and local levels (Yonezawa, 2011). Those studies showed the empirical data regarding the attention of governments in other countries regarding the importance of achieving targets towards WCU. What are the conditions in Indonesia?.

The urgency to meet WCU or globaluniversity standards also has been felt in Indonesia. But on the other hand, research on the dynamics of Indonesian Islamic-University vis-a-vis globalisation is still less to be found.
Indonesia is a country with the largest number of Muslims in the world with as many as 58 state Islamic-universities, namely 58 State-Islamicuniversities and 829 Private-Islamic-universities (Kementrian Agama Republik Indonesia, n.d.).

Regarding the availability of WCU there is a considerable difference when comparing Indonesia (as a developing country) with universities in developed countries (Murdowo, 2018). The declaration of WCU and its achievements are very according to the economic and political power, size and geographic location, dominant culture, the quality and typical features of their tertiary education system, the mother-language used in country, as well as internationalisationpolicies (OECD, 2008). Bureaucratic university governance, facilities and funding that still depend on government subsidies, as well as higher-education management still have an impact on the small-number of categorized WCU in Indonesia (Murdowo, 2018).

This study pertains to the category of Islamic-universities in Indonesia. A study by Abdullah (2017) revealed that the highereducation system in Indonesia tried to elaborate on how the Islamic-education system modified teaching methods and research to better suit the development and achievement of science, especially in humanities and social-sciences that fit the context of the present-era. Several Islamic universities in Indonesia carried out scientificintegration between science and religion, in order to follow the Indonesian-NationalQualifications-Framework-Curriculum which is often called the KKNI-curriculum. Furthermore, transformation from IAIN to UIN was a step forward for the Indonesian Islamic educationalinstitutions to be more open internationally and globally community (Abdullah, 2017; Nasrudin, Helsy, Rochman, Irwansyah, Munir, \& Mahmud, 2019).

Currently, at the international and national levels, some rating institutions present university rankings that recognise university's quality with reference to the global-standards. For example, in Webometrics (2020), IslamicHigher-education Institutes (Perguruan-TinggiKeagamaan-Islam [PTKI]) have not yet reached the "Best 15 " category on the national-scale as these universities are not under the Ministry of Education and Culture (MoE). Indonesia's 
higher-education system is divided into two parts, i.e., those under the $\mathrm{MoE}$ and those under the Ministry of Religious Affairs (MORA) (Abdullah, 2017).

On the world-ranking scale, as per Webometrics (2020), the State-Islamicuniversities in Indonesia (Universitas Islam Negeri [UIN])s, were ranked after 3,000 mainly starting at 3,354 . Also, UIN is still not found in the list of the World's Top 1,000 Universities (QS World University Rankings, 2020; Shanghai Ranking, 2020). Thus, it can be assumed that Indonesian PTKIs are still not in a position to compete with International-Higher-educationalinstitutions (IHEIs). Therefore, PTKIs need to put in more effort to compete with other IHEIs around the world. Further, Indonesian universities under MORA are also willing and aspire to become WCUs. A study by Yang \& Welch (2012) indicated that a university's framework for global-standardisation includes the commitment of the government concerned in advancing the country through education. The crisis experienced during the process made the organisation needs resilience to face all problems. To be able to develop positively from situations of stress, sudden-shock, challenges, and full of risks, the organisations need resilience capabilities to continue the struggles that have been done before and which will continue to be developed time by time for the continuity of organisation's existence (Ruiz-Martin, LópezParedes, \& Wainer, 2018).

Resilience can be analysed in the wholeorganisation, organisational-units, and the individuals concerned. It is a potency that is more than just the ability to survive and develop to achieve goals. Hence, this concept offers a potential framework to overcome damages, obstacles, gaps, and improve organisational development. In indicates the ease with which an organisation moves from stable to unstable state. As such, it includes the ability to facing current difficulties, survive recent, adaptation with the changes with all its difficulties, and then challenges of the past and future (Kendra \& Wachtendorf, 2003; de Carvalho, Ribeiro, Cirani, \& Cintra, 2016; Quendler, 2017). Challenges to be faced regarding problems of funding, participation from all humanresources in organisation, and cultural-change like the economic system and condition, globalisation, demand for particular standard for education, and invention, become important considerations for an organisation that is aware of risks, crisis management, planning continuity, organisational-leadership, and contingencybased management (Kusumaputri, Himam, Afiatin, \& Meiyanto, 2014).

Organisational-resilience has to be seen as a response by the whole system to change, an organisation's individuals and groups and the system as a whole. Organisational-members should productively respond to change and avoid regressive behaviour (Horne \& Orr, 1998). Optimism in facing change has a particular place in the case of PTKIs as it adds to their ability to compete in the international-educational field, which itself is open to change. Universities have to make strategies, plans, targets, and programs as international-standard to be competitive amid globalisation. Generous funding will be needed for the universities if they are to be established as WCUs (Salmi, 2009).

In response to the global-challenges, Islamic-higher-education in Indonesia has to demonstrate evolution and development (Abdullah, 2017). To achieve this, Indonesia's higher-education management needs the movement of people, ideas, and information, which is also a characteristic of globalisation. These requirements must be addressed by the management of Islamic-universities under the auspices of MORA. Therefore, the purpose of this study is to explore the organisationalresilience of Islamic-university in terms of challenges faced at implementing the WCUstandard and its outcomes. In view of these process and efforts, therefore this study aims to turn attention for seeking, exploring, understanding, and analysing these following matters: (1) The positive outcomes and efforts made by the Islamic-University at responding globalisation and implementing WCU-project; (2) The stress-challenges faced and the strategies used by The Islamic State of University as the Islamic-University towards globalisation?; and (3) The corporation between Islamic-University as the organisation and their academicians as human resources and organisation as a whole to handle disruptive events and survive in pursuing WCU. 


\section{METHODS}

This study used a qualitative research approach mainly the case study method to gain an understanding of the efforts of of the studied Islamic University, pseudo-named MMI-University in the vis-a-vis globalisation, particularly organisational-resilience. The data collection methods focused on in-depth interviews and gathering secondary-data through observations, photos, document analysis includes university's recap data, the university's website, and academic-documents. Interviews as the primary-data and observation and documentation for secondary-data. Purposive sampling technique was used in order to obtain the informants. This conducted using directedgeneral-interview techniques and the questions were adjusted to the respondent's circumstances face-to-face in the context of the actual-interview.

In this study, academic-documentations were needed to understand the relationship between academic-data and interviews. Also results of interviews can be understood in its context. The documentations used include: "Institutional strengthening towards the maingoal: welcoming WCU by MMI-University", "Ulul-Albab Curriculum: KKNI-based curriculum-standard based on PERMENRISTEK 2016 no.44/2015, "Pilot Project [international class program for Tarbiyah-Faculty (incubation stage)]" and Rector's Speech [MMI-University] IDB Group 41st annual meeting 2016, which these documents are closely related to the WCUimplementation.

Purposive sampling is the technique used for selecting key-informants who are considered to know well the information and problem in depth and trustworthy as data-source. The informants concerned have personal experience in accordance with the problems studied, namely organisational-resilience towards WCU and have extensive knowledge of the problem. The researchers conducted open-ended interviews with chancellor's secretary, internationalclass-program (ICP) lecturers, chairman and secretary of the university's-quality-assuranceagency (institution that carries out the process of supervision, controlling, monitoring for the achievement towards WCU), head of university library (chief-librarian), and academicians who actively participate in Rumah-Jurnal/JournalHome.
Observations and interviews were conducted for four months. All results of the interviews were recorded in audio and video formats, then it was transcribed to be used for data analysis. The data is equipped with a formal policy review from the Ministry of Religion and Ministry of Education, Culture, Research and Technology. Data analysis including: data review; organising data by coding, categorising the data, and data triangulation process; and case analysis. In the data analysis, the coding results were arranged according to the categorisation of the data. Nvivo 11 for Windows was used as the data processing tool. Information obtained from several informants about related data on several domains, namely response to globalization and implementation of WCU, the challenges faced and strategies used, the dynamic of efforts to response to the change, and challenges.

Interviews and document searches are conducted in multiple sessions to ensure data availability. Agreements precede interviews with research participants. The validity of the data uses two ways, and the first is a synchronization of interview data with university documents and two ministries. It aims to compare informant understanding and implementation. Second, validity is determined by different information categorization and data-testing using Nvivo 11 for Windows.

\section{FINDINGS AND DISCUSSION Findings}

The results of this study answering the research's aims mentioned, this will be explained from the data results (sourced from interviews, video-recordings, photo-documentation, and WCU related academic-documents). The information here includes the MMI-University's actions in responding globalisation namely: the organisational changes, processes to pursue their targets, the challenges faced, and their capability that indicates an organisational-resilience visa-vis globalisation or WCU-standard. This section explained the university's growth which reflects the impacts of globalisation and also their resilience in terms of the implications of continuous efforts to improve quality, relevance, and competitiveness. 
Response to Globalisation and Implement WCU Project (The Positive Outcomes)

After the declaration of University's development-roadmap which was divided into several phases, the outcome (Impact) of the development and upgradation of the STAIN-Malang's project showed several improvements in various aspects of the university namely from STAIN into UIN. The data from our study presented here pertains to the time after the launching of the WCU project by MORA towards MMI-University in 2013. The academic-data about the demand or registrants in MMI-University indicates an increase in both the number of registrants and the accepted-applicants, increased by $50 \%$ over three academic-years and resulted in increasing accepted students year by year. The students to have passed on the academic-year increased to $93.99 \%$ in four academic-years. The university's reputation grew as the average of their whole students' cumulative Grade-PointAverage (GPA) increased 3.32 to 3.37 over three academic-years.

An increase in the student enrolments also had an impact in terms of the growth of the university's infrastructure. The University also has attracted more international students. Over three academic-years, there were 232 students from 30 countries. Furthermore, in 2020, the university has awarded as the Indonesian Islamic-Higher-education with the most largest number foreign-students (international-class program), this award was given in the year of 2020 from ADIKTIS (Apresiasi-PendidikanTinggi-Keagamaan-Islam/The Appreciation of Islamic Religious Education), by Directorate of Islamic Religious Education, MORA of Republic of Indonesia.

The data regarding faculty's researchers indicated a $12.90 \%$ increase and the number of journal-authors also increased $12.90 \%$ in one academic-year. The number of research studies and book-publications from Institute of Research and Community Service or Lembaga-Penelitiandan-Pengabdian-Masyarakat (LP2M) increased, namely $54.92 \%$ and the published books increased $24.46 \%$ over three academic-years. Besides,
MMI-University's Jurisdictie-journal has been accredited with Science-and-Technology-Index (Sinta) 2 by Kementerian-Riset-dan-Teknologi/ Badan-Riset-dan-Inovasi-Nasional (Ministry of Research and Technology/National Agency for Research and Innovation). Furthermore, the updated data collecting from Lembaga Penjamin Mutu (LPM)/Quality Assurance Agency of MMI-University, the study-programs at MMIUniversity increased as there was improvement in the accreditation status, for those accredited $\mathrm{A}, \mathrm{B}$, and $\mathrm{C}$. The " $\mathrm{A}$ " is the most of all, " $\mathrm{B}$ " in moderate, and " $\mathrm{C}$ " score is only at one program study, and as for the institution, the university has been officially accredited A by BadanAkreditasi-Nasional-Perguruan Tinggi (BANPT)/National-Accreditation-Board-for-HigherEducation in the year of 2019. The study of international-standard has become one of the agendas in long-term planning and has been carried out by the WCU of MMI-University's team which was summarized in the development roadmap of MMI-University's continuation from 2020 which will be scheduled in its long-term program, namely 2021-2030. Furthermore, the particular courses with international-standard were held for their human resources to improve and empower their capability, including: class program of foreign language competence, lecturers' scientific works and activeness in conference, reinforcement for journal authors (training/workshop) with national \& international human-resources. Having memorandum of understanding $(\mathrm{MoU})$ with overseas-institutions (Universities in Egypt, Australia, and USA).

\section{The Challenges Faced and Strategies Used In Order to Reach WCU}

The challenges faced and efforts handled include the presenting data about the stressful events and problems arose along the WCU implementation. The challenges and its responses from every problem will be explained. Those become challenges faced and the strategies used by MMI-University as the Islamic-university vis-a-vis globalisation. The schema of challenges faced and the strategies used is drawn in Figure 1. 


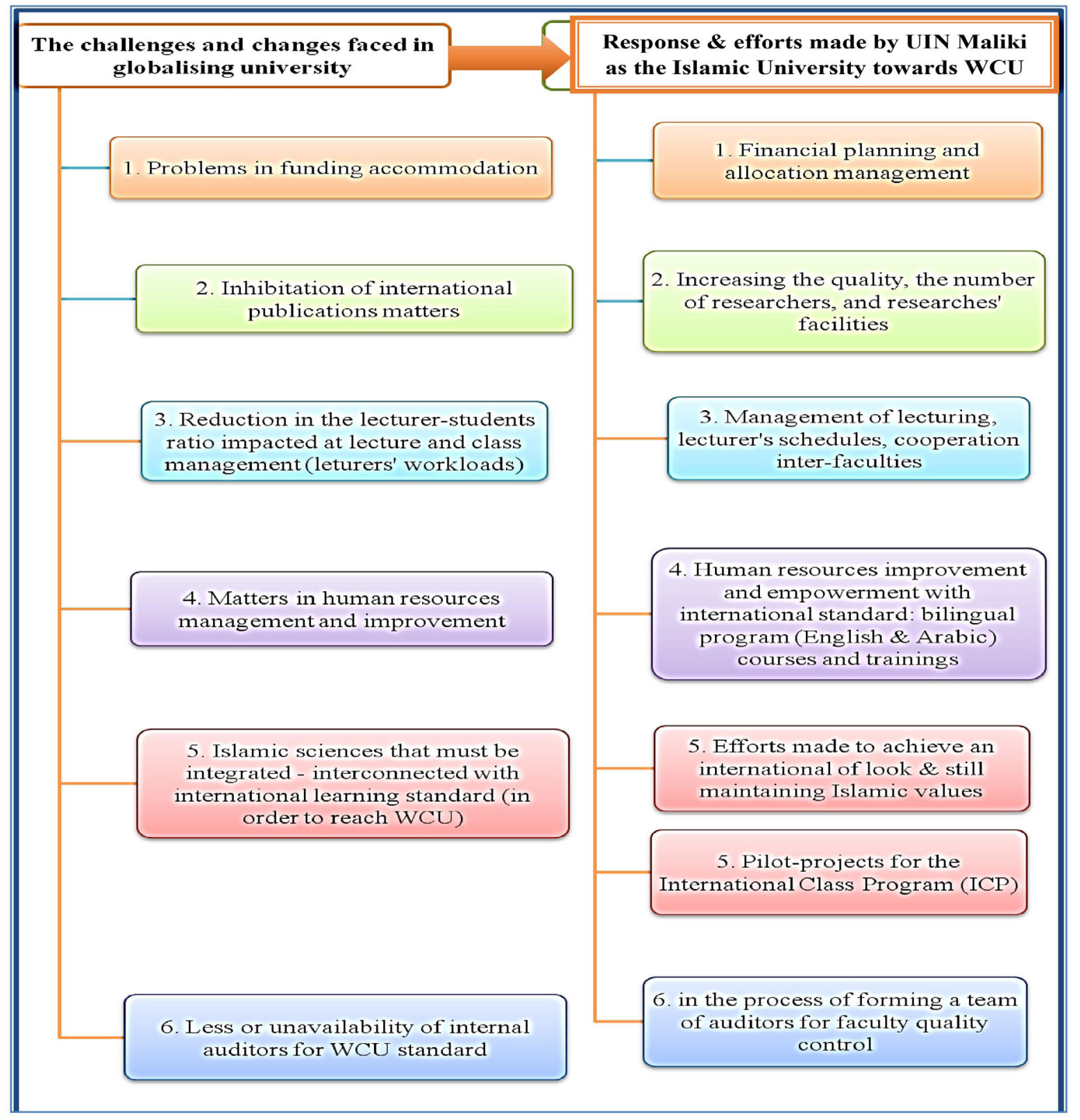

Figure 1. The Challenges and Responses in Globalising University

The challenges faced are explained in the following: 1) Problems in funding accommodation. Funding cuts resulting in constrained research publication \& overseas cooperation (This has an impact on constrained research and publication; the cooperation with institutions from abroad began not running smoothly because of cuts-funding), the low commitment in budgeting from the government, and taking over of funding. From the results of interviews with the Secretary of the Chancellor and Lecturer of ICP it is recognized that the commitment from MORA is still low (MORA has given a mandate to MMI-University to achieve international-standards in 2013), but commitment in the field of budgeting is low (acquisition of funds in 2016). The results of interviews showed that there was a cut in funds which resulted in hampered research and publications. This has also resulted in less smooth cooperation with overseas institutions. Regarding the support of human resources, budgets, and others, it has not been felt as a form of support from MORA for the policy of making MMI-University as a WCU Islamic-university. The results of interviews with the WCU-team showed that there is a policy from the government to take over the funding in the midst of university was trying to optimize research products.

2) International publications matter, 
include: Less availability access (the limitedaccess of international Islamic journal compared to the public scientific journal), from the interview, it was stated that the availability of nationally accredited religious-journals was widely available. But however, as what has been felt by the academicians in MMUniversity the availability of internationaljournals to accommodate religious research is still less, this has an impact on lecturers in the religious-department in finding references to international-journal studies. In addition, these publications have not yet been accommodated by the LP2M. Consequently, not all but only a few of the research studies are published because of the limited quota of resources meant to deal with this matter. The management of the journalhome (initiated by the Head of the Library) and its sustainability is still not formally inaugurated by the university, the legality of the journalhome is still separate from LP2M even though it has become a gathering place for writers and a home for academicians to write scientific-work.

3) Reduction in the lecturer-student ratio. In order of the postgraduate managed WCU, it had an impact on reducing the teaching schedule for lecturers, resulted lecturer-student ratio in writing. The slow progress of the doctoralprogram due to the level of office-grade-position turned out to be urgent in the professorship program because on an average the teaching staff who were proposed to be professors were in the grade of group IV civil servants and mostly at IV/c (the highest grade being IV/e). Every faculty had to contribute its human resources to reach the target determined by the universityleader. Therefore, a special plan emerged to recruit lecturers during the WCU memoratorium but must remain as needed to increase the lecturer-student ratio in scientific-writing.

4) Matters in human resources management and improvement, include: The basic lecturers' knowledge and studies (in MMI-University as the Islamic higher education, its lecturers are basically from pure Islamic-studies), in order to go to WCU then the lecturers' knowledge must be integrated-interconnected into sciences (natural, social, as well as cultural sciences); and English language barriers among humanresources in MM-University.

5) International learning-standard. The curriculum that must be integrated with Islamic- values, include: international class management in faculty of Tarbiyah (Arabic term for "education"), integrated curriculum of Islamic values (based on Islamic Al-Qur'an-Hadits) and international-curriculum standard, in process for information-technology (IT) updates for public \& globally access available in English and Arabic language.

6) Less availability of internal auditors for faculty's quality control: There must be faculty'squality-controllers who are in the stage process of implementing WCU project. The process of forming a team of auditors, and the percentage of study-programs those have been standardised internationally.

\section{Response \& Efforts (strategies used) towards WCU Implementation}

1) Financial planning and allocation management: Cooperation with foreign countries runs smoothly in almost every faculty at the time of funding from the government, so when there is a transfer of funds, management of internalexternal cooperation with other institutions both inside country and other countries (overseas) become important things that the university pays attention to; to continue the cooperation program with universities abroad, then survival with existing funds. Besides that, lecturers make training independently without special-budget, and carry out journal-home for research centre. In the context of accelerating lecturers to achieve professorship degrees program carried out by universities, one of them is by providing funds for international-conferences and publishing journals for lecturers who are in the process of completing the professorship program.

2) Increasing the quality, the number of researchers, and researches' facilities, include: a) Mastery of basic science and technology; b) Learning and community service activities; c) Disseminating research results through scientific communication media; d) Journal of international reputation: Journal of Islamic Architecture. Two journals for the publication of research and one journal for the results of community service; e) Knowledge and experience sharing, training, workshops, sharing, discussions, access to national and international-journals, journal house facilities, and giving rewards; f) A collaboration of a university's library and rumah jurnal (journal-home). 
To foster the enthusiasm of lecturers to write and also become a gathering place for academicians who want to discuss their research, library and journal-home hold supporting activities including: discussion and sharing, namely the initiative of lecturers to hold weekly discussions to talk about how fellow lecturers write and can translucent to internationally accredited journals. Knowledge and experience sharing is carried out by presenting resourcepersons from various countries, exchanging ideas, so that lecturers become familiar with international reputable journals. The existence of this journal-home fosters the enthusiasm of lecturers trying to publish their studies in journals because it is supported by many factors, including: training, workshops, sharing, discussions, access to national and internationaljournals, room-facilities and office-tools in the journal-home, also giving rewards for lecturers whose work has published in journal indexed SCOPUS. The journal-home also holds a research data-bank, all research outputs managed by the lecturers are stored in the journal-home

3) Management of lecturing, include: In order to meet the target to achieve WCU and at the same time to improve the knowledge of lecturers, professor acceleration funds are provided for professor programs. Those who are completing the professorship program receive support for the acceleration of scientificwork and got reduced teaching-load. The management of the lecturer's teaching schedule for the acceleration of professors is carried out to support the smooth running their education to reach professorship. Each faculty contributes for providing human-resources to achieve the targets set by university leaders. LPM makes a contribution as a place for a consultation to manage the workload of lecturers. This indicated the cooperation between academicians and each faculty in university.

4) Human resources improvement and empowerment with international-standard: In order to reach WCU, mastery of English as an international language, makes MMI-university concentrate on improving the English language skills of office staff and educators. This was happily welcomed by academicians. This was carried out through training that was previously carried out on a mapping strategy to improve language skills, then the departure of human- resources training (in collaboration with international-scale English training courses, domestically and abroad, namely in Bali and Malaysia). Activities undertaken to achieve international-standards include: bilingual program (English \& Arabic) in lecturing, funds for international-journal needs and journals for lecturers of completing a professorship-program, and English-courses for human-resources both academicians and staff-officers. The university also encourages and does lecturers' selection to attend international-conferences and provides funds for international-conferences and journal publications.

5) Achieving an international of look with still maintaining Islamic values: The science developed at MMI-University follows the theoanthropocentric paradigm that pays attention to universal human values and is based on Al-Qur'an and As-Sunnah. The principle is to maintain the good traditions (turas) and take-up the new better practice (al-muhafadat-ala-'I-Qadim-as-Salih wa'I-akhzu-bi- 'i-jadid-al-Aslah). Therefore, the programs made and developed by university are educational activities those cannot be separated from Islamic-religion. Some programs were made towards globalisation with still maintaining the Islamic-values, as like: the "Ulul-Albab curriculum" (along with Kerangka-KualifikasiNasional-Indonesia [KKNI], and continue maintaining MMI-University's curriculum with integrated paradigm). This curriculum integrated between the secular-sciences and Islamicknowledge from Qur'an-Hadits. Implementing the Islamic-studies curriculum in the lecture system with an integration-interconnection of paradigm between secular-sciences and Islamicphilosophy of knowledge (Islamic-science, Islamic-framework) by: Tahfidz Al-Qur'an (Qur'an-memorisation); intensive learning of Arabic and English; Islamic boarding-house program (Ma'had) for MMI-University's collegestudents, and the Islamic-standard namely UlulAlbab (Arabic terms means "people who have multi-layered brains") curriculum.

6) Pilot-projects for the international class program (ICP): When receiving a WCU mandate, the university re-evaluates the ICP that has been applied before. MMI-University also achieved an international-cognition (ICP and AUN-QA [Asean-University-Network-QualityAssurance], in process). There is a special test 
for students who pass the ICP selection. After students entering the first semester, there is a follow-up test, namely language-skills-test and academic-potential-test (in quality performance standards for international test-book projects). The lecture consists of three stages including the incubation cycle, initiation cycle, and maturity cycle which will be carried out until the seventh semester. The incubation period is the preinternational-class stage, namely internalisation and habituation of communication with international-languages, thus requiring lecturers to be able to deliver material in English. Diplomas are also published in three languages, namely Indonesian, Arabic, and English, accompanied by a certificate accompanying the diploma.

7) In the process of forming auditorsteam for faculty's quality control, it was done by: Forming a quality assurance unit in each faculty to supplement the university's efforts to improve human resources as the member of organisation, ICP evaluation in one of the faculties (Tarbiyah faculty) which is considered successful to become one of the standards for ICP development in other faculties. Evaluation is carried out according to the department's performance indicators. It is also shown that the measurement document of the department's performance indicator instrument is prepared in detail both from the instrument itself and also an explanation of the scoring procedure. ICP evaluation in one of the faculties (TarbiyahFaculty) that is considered successful; to become one of the standards of ICP development in other faculties. The learning evaluation system is carried out every four years or adjustments to new government regulations that have an impact on changing course codes and so on with certain mechanisms.

\section{The Dynamic of Efforts in Response the Change and Challenges}

Various efforts were undertaken by MMIUniversity as an Islamic-University towards globalisation, carrying out the mandate from MORA to become PTAIN with a global-standard while maintaining Islamic-characteristics and values. In order to maintain the Islamic-values, MMI-University has developed curriculum called "Akumutu-Ulul-Albab" then developed indicators into a standard.

The reasoning for MMI-University becoming WCU is the recognition that the international-standard for an institution is measured by using the parameters of progress and achievements. For a university, the parameters include academic human resources, developed research, graduates needed by the market, scientific work published, benefits for the public, and other academic achievements. To be able to reach this goal, some traditions and values that need to be developed such as discipline, a strong work ethic, skills, commitment, objective, and passion for knowledge.

Organisational-change and movement in facing globalisation is drawn in the following figure (Figure 2) that explains the dynamics related to the university's efforts to address the changes and challenges faced.

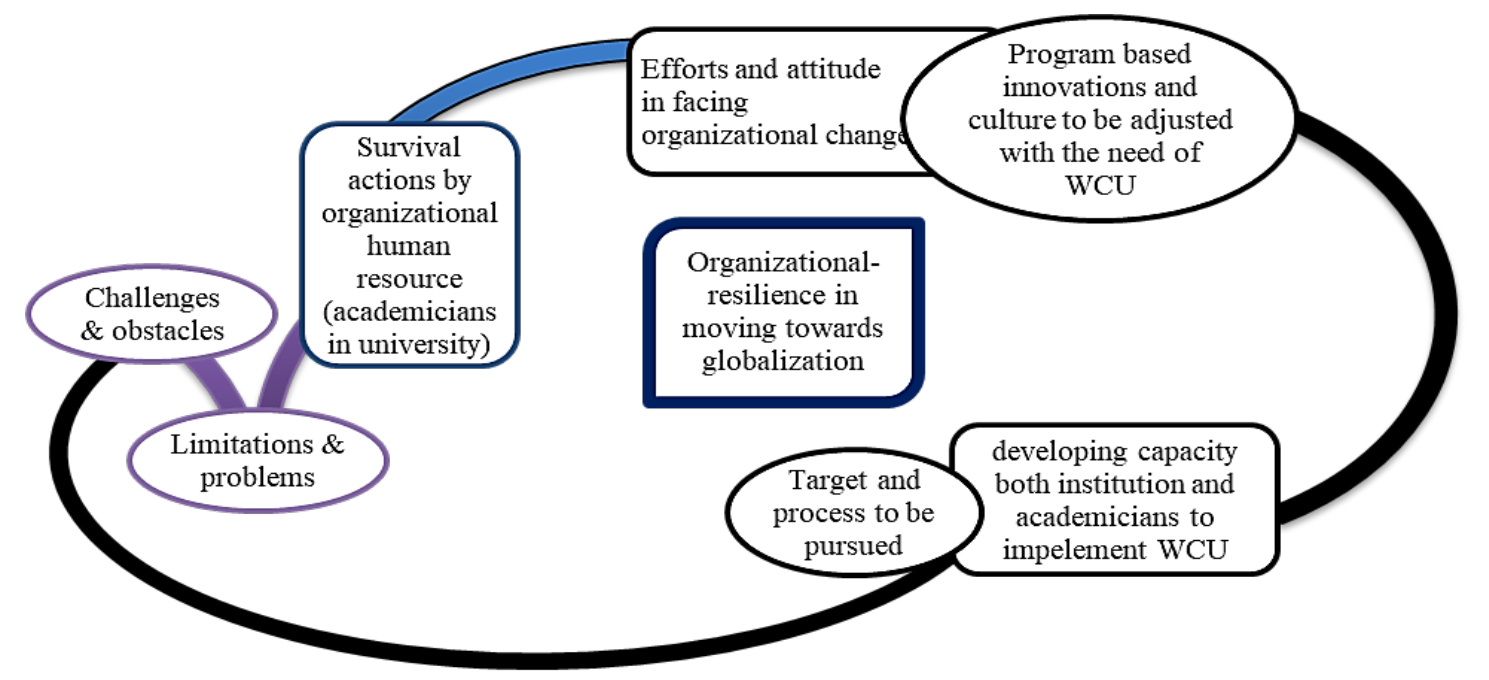

Figure 2. The Dynamics of Organisational-Resilience at MMI-University 
It shows that the actions and responses of MMI-University towards attaining the WCU faced constraints and challenges that caused limitations in carrying out the programs or plans conducted by it at this pilot project stage. In the midst of many problems with limitations faced by MMI-University in the context of implementing WCU-project, including financial-problem, challenges of managing international-standard programs, resources, institutional-sustainability in managing programs, and maintaining the Islamic-values, it is necessary to have resilience so that they can rise from the pressures, crises, and problems at hand. It was understood from the interviews, even though MORA had given the mandate to the university to attain an international-standard, yet the government's commitment for budgetary-support was still low after some years. The government's policy took over the funding in the middle of MMIUniversity's efforts to optimise their research products caused constraints for its research and publications.

The sustainability of the journal-home has not been formalised by the university yet. It is still not on legally firm ground as it is not connected with the LP2M though it has become a centre scientific-work by academicians. The library becomes place to implement to anchor it. To add to their knowledge in the sphere of writing scientific-papers, the lecturers themselves took initiative to learn together during semester breaks, they scheduled training sessions for themselves. The lecturers enthusiastically consulted with their colleagues in the journal-home. Besides, MMI-University also has shown willingness to learn research publication through consultation with other universities who have reached the WCU-status. Programs based-innovation was done in order to implement WCU project as the related targets to be achieved by MMI-University in the mid of fund limitation.

\section{Discussion}

This chapter discusses organisationalresilience in Islamic higher-education: challenges faced in moving towards globalisation namely the challenges faced by MMI-University as the Islamic higher-education, how to survive, and overcome. It is the organisational-resilience that enables an organisation to cope with the challenges and obstacles those encounters.
Aspects of organisational-resilience include an organisation's ability to do the following: change with minimal friction in times of changing contexts by showing due flexibility and plasticity; withstand sudden shocks; and return to the desired balance, both the previous and the new, while still maintaining the continuity of their operations (de Carvalho et al., 2016). Lengnick-Hall, Beck, \& Lengnick-Hall (2011) found that the resilience of organisation actions in overcoming a disruptive threat by combining knowledge, skills, ability, and the routines performed. The ability to overcome difficulties and respond to situations and environmental conditions will be needed in this case of Islamicuniversity.

According to Salmi(2009), foreducationalinstitutions, positive results with regard to global flows require resources (funding, ideas, students, and academic-staff). Without these, they may not be able to survive internationally. The importance of funding in this regard also aligns with what has been stated by Salmi (2009). This has forced the state's institutions of higher-education to re-examine their missions. In addition, these pressures have forced the government to walk some distance, especially with regard to allocate funding available for tertiary education and to re-examine their commitments and expectations from their institutions of higher-education (Salmi, 2009). Zhou (2017) mentioned that the government's investment is very important for the development of higher-education. But it takes generations of academics to build a WCU.

The policies from government and practices of multi-academic sponsors determine the autonomy of the academic community in the chain of the system (Salokangas \& Chapman, 2014). Consequently, the autonomy level of the academic-community varies significantly. One striking feature of the situation in China is the level of commitment shown by both parties, i.e., the government and the institutions concerned to attain the WCU-status government also contributed in terms of supportive-policies and impressive-investment for WCU. This was experienced MMI-University in early year after the WCU-mandate, the budgetary issues and other matters have not been felt yet because the other support received from MORA towards the policy to make Islamic-universities gain an international reputation. But lately years namely 
at 2016 they faced funding-cut problem, that impacted in many aspects. On the other hand, to keep moving forward in pursuing $\mathrm{WCU}$, the university has to handle it itself and deal with it. Considering the conditions in Indonesia with all its bureaucracy, in order to survive to maintain its WCU ideals, the impact is that universities themselves must be financially independent and the ability to invest is important, without taking too much of the government budget and subsidies, the existing subsidies must be allocated. Effectively on investments that contribute to increased competitiveness, such as multiplied research grants and increased foreign cooperation (Murdowo, 2018).

This is important not only from a financial perspective but also because it leads to high moral and enthusiasm among those working on the frontline. By strengthening its research capacity, university could make appropriate changes to the way they collaborated with their international partners. Previously, this collaboration and international exchange were mostly limited to the exchange of personnel and information (Zhou, 2017).

However, amid the funding problem, the academic community is still trying to maintain and foster among the lecturers the spirit of writing and publishing their works. The solution is the establishment of a journal-home to accommodate the researchers. The lecturers are being encouraged to publish their research and then transform it into articles that comply with international-publication-standards. When mild stress affects organisations due to a change, it needs their organisational-members to respond quickly and effectively to the change (Limnios, Mazzarol, Ghadouani, \& Schilizzi, 2014). To cope with such problems, MMI-University was helped by its journal-home (rumah-jurnal) which has developed a platform called repository research to collect the research data (inputsoutputs) from all researchers. This initiative came from the library director for research management and the lecturers appreciated this program.

From the research results it was found that the existence of this journal-home fosters the enthusiasm of lecturers to try to publish their studies in journals. Furthermore, there is rewards for lecturers whose work published in SCOPUS. Tierney (2014) wrote that the reward structure is also directed at achieving university's goals who want to reach WCU. When rewards are clearly formulated, it will create a sense in individuals about what they have to do to achieve these goals. In this regard, the success in publishing scientific papers in SCOPUS-indexed-journals is one of the strong aspects of achieving WCUstandards. Any strategy at the level of institution to build a WCU needs strong leadership, a firm vision regarding the institution's mission and goals, and clear strategic-planning that is articulated to translate the vision into targets and concrete programs (Salmi, 2009). These values emphasise the importance of developing an individual's working competence in an organisation and helping them to get worksatisfaction (Kusumaputri et al., 2014). In this case, the academic community works together to appreciate their journals' publication.

However, the journal-home initiative became a means to gather and share experiences. There is an awareness (an attitude that helps change) among academicians with regard to the global competition they face. This follows what was stated by Horne \& Orr (1998) about individuals who, as a part of a system, take the perspective to keep moving as changes take place in the whole system in their organisation. Such resilient individuals in the organisation can make a difference as their collective action can create an organisational-resilient response. For example, with regard to the declaration of the WCU-project, a university in China decided that it must meet the standards regarding scientific, technical, and human resources, and started to offer a series of advanced degree programs (Choi, 2010; Zhou, 2017).

To be resilient despite limited funds, MMI-University organised a volunteering program for getting help for the LP2M regarding data collection and field research such as helping in the community service program and related research. For example, it is the volunteering program of the kuliah-kerja-nyata (KKN) or community service program and praktik-kerjalapangan (PKL) or professional-placementpractice. The volunteers (at KKN) who were involved in the program received substitutions instead of material-things.

Cooperation between individuals in the form of a revitalisation movement was initiated by academicians, i.e. as for the curriculum, 
according to Islamic-teachings is summarised in the target and process (goal-setting) of university, namely the development roadmap which is the stabilization of "Integration of Islam and Science" Program, resulted in UlulAlbab Curriculum. They have successfully made integration-interconnection of sciences and Islamic-values as MMI-University as the university-based-religion. This likely written by Dunn (2020) took from Rafastari that community under religious-organization can globally competitive although they still maintain their ideology. This can be inferred as the creative resilience effort in the context of globalisation that requires support from individual, national, and regional units (in his study, Dunn called it as the globalisation from within). MMI-University and its members as a whole system can maintain their Islamic identity and characteristic even as they compete internationally.

Challenges that arise from within the organisation are related to the absence of controllers of faculty-quality. The solution provided by the WCU-team concerned was to propose and strive for the university to form a quality-assurance-unit in each faculty to supplement the university's efforts to improve human-resources. Additionally, the WCU-team will provide an IT application to make sure all standards are applied to and fulfilled in each faculty. To overcome this matter, the evaluation of ICP in one of the faculties (Tarbiyah) that was considered successful was made the benchmark for the development of ICP in other faculties. The evaluation of each department is in accordance with the respective study program's performance indicators.

Choi (2010) pointed to a similar case vis-a-vis the Yanbian-University. When they experienced exponential growth in registrations, faculties, and facilities, considering that time was right to move to meet global-standards. However, despite real optimism among the campus community, being a minority campus, experienced significant challenges. Most of these challenges probably came from the university's dual function, which, on the one hand, was to maintain their traditional mission to preserve the ethnic characters and serve the resident community and, on the other, was to deal with their new mission regarding mainstreaming their institution and graduates (Choi, 2010).
To manage the WCU-program, the number of lecturers had to be reduced. The challenges related to the lecturers-students ratio also became a problem for MMI-University as it had a negative impact on productivity of scientific journal writing. The lecturers' scientific integration was done because on average the lecturers at MMI-University were basically recruited on civil science to work on the WCU-project and were finally integrated into the science faculty (vice versa). Their scientific integration was done through organising training for lecturers.

The LP2M contributed to the program as a consultation home for the faculties to manage their lecturers' workloads. As per a study by Chewning, Lai, \& Doerfel (2012), the resilience of organisations is their overall direction determined by their members who work together. Organisational-resilience needs the various dimensions of ability and adaptability formed by the organisation.

MMI-University's IT upgradation is still in progress to meet all the standards that apply to each faculty. The reports and data on MMIUniversity's achievements is in process to be systemically collected. This work is still in progress for the preparation of the Accreditation of Higher-education Institutions, includes several aspects such as cooperation, research, scientific-work, and journals. In addition, the university's academic administration department under the Bureau of Academic Administration, University Students Affairs and Cooperation, has provided, archived, and reported the entire set of academic-data and academic-documents in a detailed and systematic manner. This data has also been arranged semester-wise.

The results of the present study have revealed the continuous efforts undertaken in improving the quality, resilience, and competitiveness in the global world. One such effort was the successful transformation of the institution from a faculty to a separate university within a few years. Based on the findings of this study, alterations at the individual level also become a determinant of successful change. They have done efforts to enhance the management, academic-community's knowledge and skills, international-curriculum standardisation, and internal and external cooperation with overseasinstitutions were found to be continuously 
encouraged. Further, these efforts were inseparable from the challenges faced both internally and externally, e.g. policies related to funding, time length duration of study, running the integrative curriculum of religionbased curriculum and secular subjects, and other matters related to the management of Islamic-University vis-a-vis WCU. Although the institution encountered many challenges, the efforts of those concerned indicated their adaptability to remain steadfast in difficult situations. This is indicative of organisationalresilience.

\section{CONCLUSION}

MMI-University has experienced several improvements in terms of the applicants enrolled, the graduates, GPA-values of the graduates, the number of books and journals published, and the number of accredited study programs. The university's organisational-resilience has been manifested though it is not optimal yet in terms of the situation of an IHEI (or PTKI) becoming a WCU. MMI-University integratedinterconnected the curriculum between sciences and religion, they have successfully implemented the Ulil-Albab Curriculum. Some externalcooperations done by MMI-University to reach WCU include: (1) Presenting expert-lecturers from overseas countries, (2) Participation of MMI-University's lecturers to teach in one university in Egypt, (3) International of look at cooperation in the form of joint activities with several universities at international level, (4) Organising cooperation with industry and relevant institutions for capacity building in science and technology, (5) English training for academicians and university's staff-officers. In addition, ensuring the curriculum development and standardisation, providing facilities and infrastructure matched with internationalstandards including multilingual (four languages i.e. Indonesian, English, Arabic, and Chinese) information about the university on its website and carrying out the website's evaluation. This will greatly read in getting the information related to MMI-University through the internet, Bahasa Indonesia represents the mother tongue of most of the residents of Indonesia (also university's location), Arabic represents the language of Al-Qur'an, i.e., the holy book of
Islam, English represents the global language, and Mandarin represents the language used by the largest population in the world today. Further, given the foreign language, constraints the empowerment and development of human resources to measure up to the internationalstandard has been a challenge. Currently, the academic community of MMI-University is in the process of implementing their plans that have been made to reach their target of becoming a WCU. Despite encountering many challenges, the efforts that emerged indicated MMIUniversity's adaptability to remain steadfast in difficult situations (resilience). Currently, the university's academic community is in the process of running/implementing their strategicplans to reach WCU and the target to compete globally as the Islamic-University vis-à-vis globalisation.

\section{ACKNOWLEDGEMENTS}

The authors would like to thank and acknowledge for Lembaga-Penelitian dan Pengabdian-Masyarakat (LPPM) (the Research-Institutions and CommunityServices), State Islamic-University of Sunan Kalijaga Yogyakarta, to have supported-funding on this study, and for all MMI-University studyparticipants from who have been kindly open for the data.

\section{REFERENCES}

Abdullah, M. A. (2017). Islamic studies in higher-education in Indonesia: Challenges, impact and prospects for the world community. Al-Jami'ah: Journal of Islamic Studies, 55(2), 391-426. https:// doi.org/10.14421/ajis.2017.552.391-426.

Byram, M. (2018). Internationalisation in higher education -an internationalist perspective. On the Horizon, 26(2), 148-156. https:// doi.org/10.1108/OTH-11-2017-0090.

Chewning, L. V., Lai, C. -H., \& Doerfel, M. L. (2012). Organizational-resilience and using information and communication technologies to rebuild communication structures. Management Communication Quarterly, 27(2), 237-263. https://doi. org/10.1177/0893318912465815. 
Choi, S. (2010). Globalization, China's drive for world-class universities (211 project) and the challenges of ethnic minority highereducation: the case of Yanbian University. Asia Pacific Education Review, 11(2), 169-178. https://doi.org/10.1007/s12564010-9076-2.

De Carvalho, A. O., Ribeiro, I., Cirani, C. B. S., \& Cintra, R. F. (2016). Organizationalresilience: a comparative study between innovative and non-innovative companies based on the financial performance analysis. International-journal of Innovation, 4(1), 58-69. https://doi. org/10.5585/iji.v4i1.73.

de Wit, H. (2020). Internationalization of higher education: the need for a more ethical and qualitative approach. Journal of International Students, 10(1), i-iv. https:// doi.org/10.32674/jis.v10i1.1893.

Dunn, H. S. (2020). Creative resilience and globalization from within: evolving constructs for analysing culture, innovation, and enterprise in the global south. Annals of the International Communication Association, 44(1), 4-18. https://doi.org/10.1080/23808985.2018.1 $\underline{547121 .}$.

Horne, III, J. F., \& Orr, J. E. (1998). Assessing behaviors that create resilient organizations. Employment Relations Today, 24(4), 29-39. https://doi. org/10.1002/ert.3910240405.

Kashkan, G., \& Egorova, M. (2015). Problems and outlooks of international integration of higher education. International Education Studies, 8(7), 250-255. http:// dx.doi.org/10.5539/ies.v8n7p250.

Kementrian Agama Republik Indonesia. (n.d.). Perguruan Tinggi Agama Islam NegeriPerguruan Tinggi Agama Islam Swasta. [State Islamic College - Private Islamic College]. http://diktis.kemenag.go.id/ bansos/cari_nspt.php.

Kendra, J. M., \& Wachtendorf, T. (2003). Elements of resilience after the world trade center disaster: reconstituting New
York city's emergency operations center. Disasters, 27(1), 37-53. https://doi. org/10.1111/1467-7717.00218.

Knight, J. (2006). Higher-education crossing borders: A guide to the implications of the general agreement on trade in services (GATS) for Cross-border education (programme and meeting document, ED.2006/WS/61). https://unesdoc.unesco. org/ark:/48223/pf0000147363.

Kusumaputri, E. S., Himam, F., Afiatin, T., \& Meiyanto, I. S. (2014). A model of the commitment to change in higher-education. ANIMA Indonesian Psychological Journal, 30(1), 8-25. https://doi.org/10.24123/aipj.v30i1.532.

Lengnick-Hall, C. A., Beck T. E., \& LengnickHall, M. L. (2011). Developing a capacity for organizational-resilience through strategic human resource management. Human Resource Management Review 21(3), 243-255. https://doi.org/10.1016/j. hrmr.2010.07.001.

Limnios, E. A. M., Mazzarol, T., Ghadouani, A., \& Schilizzi, S. G. M. (2014). The resilience architecture framework: Four organizational archetypes. European Management Journal, 32(1), 104-116. https://doi.org/10.1016/j. emj.2012.11.007.

Nasrudin, D., Helsy, I., Rochman, C., Irwansyah, F. S., Munir, M., \& Mahmud, M. (2019). Science education at Islamic university: Vision and distinction. Journal of Physics: Conference Series, 1280(3), 1-6. http://doi. org/10.1088/1742-6596/1280/3/032060.

Murdowo, D. (2018). In what ways university in Indonesia as world-class university can produce a global competitive human capital (case study: Telkom University), International Journal of Humanities and Social Science, 8(6), 36-43. https://doi. org/10.30845/ijhss.v8n6a5.

OECD. (2008). Internationalisation: Shaping strategies in the national context. In Tertiary education for the knowledge society (Vol 1 \& 2 ). Paris: OECD 
Publishing, pp. 235-309. https://doi. org/10.1787/9789264046535-13-en.

QS World University Rankings. (2020). Discover the world's top universities. Explore the QS World University Rankings ${ }^{\circledR}$ 2020. https://www.topuniversities.com/ university-rankings/world-universityrankings/2020.

Quendler, E. (2017). Organizational resilience: Building business value in a changing world. Journal for International Business and Enterpreneurship Development, 10(2), 534-553. https://doi.org/10.1504/ jibed.2017.084301.

Ruiz-Martin, C., López-Paredes, A., Wainer, G. (2018). What we know and do not know about organizational resilience. International-journal of Production Management and Engineering, 6(1), 11-28. https://doi.org/10.4995/ ijpme.2018.7898.

Sá, M. J., \& Serpa, S. (2020). Cultural dimension in internationalization of the curriculum in higher education. Education Sciences, 10(12), 250-255. https://doi.org/10.3390/ educsci10120375.

Salmi, J. (2009). The challenge of establishing world-class universities. Washington DC: The International Bank for Reconstruction and Development, The World Bank. https://doi.org/10.1596/978-0-82137865-6.

Salokangas, M. \& Chapman, C. (2014). Exploring governance in two chains of academy schools: A comparative case study. Educational Management Administration \& Leadership, 42(3), 372-386. https:// doi.org/10.1177/1741143214521588.

Seong, S., Popper, S. W., Goldman, C. A., Evans, D. K., \& Grammich, C. A. (2008).
Brain Korea 21 phase II a new evaluation model. Santa Monica, CA: Rand. https:// www.rand.org/content/dam/rand/pubs/ monographs/2008/RAND_MG711.pdf.

Shanghai Ranking. (2020). 2020 Academic Ranking of World Universities. http:// www.shanghairanking.com/rankings/ arwu/2020.

Tierney, W. G. (2014). Creating culture of innovation: The Challenge in Becoming and Staying a World-Class University. California, CA: University of Southern California. https://pullias. usc.edu/download/creating-a-culture-ofinnovation-the-challenge-in-becomingand-staying-a-world-class-university/?wp $\mathrm{dmdl}=15661$ \&ind $=1532023232544$.

Webometrics. (2020). Ranking Web of Universities: World-ranking July 2020, Edition 2020.2.3. www.webometrics. info/en/search/Rankings/Universitas $\% 20$ Islam\%20negeri.

Yang, R., \& Welch, A. (2012). A worldclass university in China? The case of Tsinghua. Higher-Education, 63(5), 645666. https://doi.org/10.1007/s10734-0119465-4.

Yonezawa, A. (2011) The "Global 30" and the consequences of selecting "world-class universities' in Japan. In N. C. Liu, Q. Wang, \& Y. Cheng (Eds.). Paths to a world-class university: Lessons from practices and experiences. Rotterdam, Netherlands: Sense Publishers, pp. 67-82. https://doi.org/10.1007/978-94-6091$\underline{355-6}$.

Zhou, Z. (2017). Road to the world-class university. Editorial National Science Review, 4(1), 1. https://doi.org/10.1093/ nsr/nww087. 